\title{
Pengaruh regulasi diri dan kedisiplinan terhadap kemandirian belajar siswa di sekolah dasar
}

\author{
Arifah Yuli Purwaningsih*, Herwin Herwin \\ Pendidikan Sekolah Dasar, Fakultas Ilmu Pendidikan, Universitas Negeri Yogyakarta \\ Jalan Colombo No. 1, Karangmalang, Yogyakarta, 55281, Indonesia \\ *Corresponding Author. e-mail: arifahyuli.2017@student.uny.ac.id
}

\begin{abstract}
Abstrak
Regulasi diri dan kedisiplinan dapat mempengaruhi kemandirian belajar siswa. Kemandirian belajar memungkinkan siswa menjadi individu yang mampu menyelesaikan masalah dalam belajar. Penelitian ini bertujuan untuk mengetahui pengaruh regulasi diri dan kedisiplinan siswa terhadap kemandirian siswa sekolah dasar. Penelitian ini menggunakan pendekatan penelitian kuantitatif dengan jenis ex-post facto. Penelitian ini dilaksanakan di SD Negeri Kepatihan Purworejo, SD Negeri Sebomenggalan, SD Negeri 2 Baledono, Kecamatan Purworejo, Kabupaten Purworejo. Sampel penelitian sebanyak 56 siswa yang dipilih secara random. Data dikumpulkan dengan menggunakan skala psikologi serta dianalisis dengan menggunakan statistik deskriptif dan statistik inferensial melalui analisis regresi. Hasil penelitian menunjukkan bahwa regulasi diri secara parsial berpengaruh terhadap kemandirian belajar siswa; kedisiplinan secara parsial berpengaruh terhadap kemandirian belajar siswa; serta regulasi diri dan kedisiplinan secara bersama-sama berpengaruh terhadap kemandirian belajar siswa. Berdasarkan hasil tersebut guru dapat melakukan pembelajaran menjadi lebih kreatif dan bersifat student centered. Pengoptimalan kedisiplinan dengan memberikan sanksi dan reward yang positif secara adil dan korektif.

Kata Kunci: regulasi diri, kedisiplinan, kemandirian
\end{abstract}

\section{The influence of self-regulation and discipline on the independence of student in elementary schools}

\begin{abstract}
Rules and discipline can affect student learning independence. Learning independence allows students to become individuals who can solve problems in learning. This study aims to determine the influence of selfregulation and student discipline on the independence of elementary school students. This research uses a quantitative research approach with ex-post facto type. This research was conducted at SD Negeri Kepatihan Purworejo, SD Negeri Sebomenggalan, SD Negeri 2 Baledono, Purworejo District, Purworejo Regency. The research sample of 56 students were chosen randomly. Data were collected using psychology scale and analyzed using descriptive statistics and inferential statistics through regression analysis. The results showed that self-regulation partially influences student learning independence; discipline partially influences the independence of student learning; and self-regulation and discipline together influence student learning independence. Based on these results teachers can make learning more creative and student centered. Optimizing discipline by providing positive and corrective punishment and positive rewards.
\end{abstract}

Keywords: self-regulation, discipline, independence

How to Cite: Purwaningsih, A. Y., \& Herwin, H. (2020). Pengaruh regulasi diri dan kedisiplinan terhadap kemandirian belajar siswa di sekolah dasar. Jurnal Penelitian Ilmu Pendidikan, 13(1), 22-30. doi: https://doi.org/10.21831/jpipfip.v13i1.29662.

Received 16-01-2020; Received in revised from 14-02-2020; Accepted 27-02-2020

This is an open-access article under the $\underline{\mathrm{CC}-\mathrm{BY}-\mathrm{SA}}$ license. 
Jurnal Penelitian Ilmu Pendidikan,13 (1), 2020 - 23

Arifah Yuli Purwaningsih \& Herwin

\section{PENDAHULUAN}

Pendidikan di sekolah idealnya mampu mengembangkan kemampuan siswa agar seluruh fungsi pendidikan dapat tercapai. Apabila fungsi pendidikan dapat dicapai, generasi yang terbentuk tentu adalah mereka yang siap menghadapi zaman yang terus berubah. Akan tetapi, idealitas ini masih kurang sesuai dengan realitas yang ada di lapangan. Fungsi dari pendidikan belum mampu dicapai dengan maksimal, sehingga masih ada beberapa potensi yang perlu dilakukan perbaikan.

Berdasarkan hasil observasi yang dilakukan di sekolah dasar Kecamatan Purworejo menunjukkan beberapa permasalahan. Hal yang pertama yaitu kemandirian belajar siswa masih belum terlihat pada siswa kelas IV. Rendahnya kemandirian belajar siswa sekolah dasar. Hal tersebut dibuktikan dengan masih banyak siswa yang menunggu teman lain untuk mengerjakan tugas individu. Bukti lainnya yang mendukung permasalahan tersebut ialah siswa tidak mampu menahan diri untuk saling bertukar jawaban ketika mengerjakan tugas individu, siswa masih bergantung pada guru sebagai sumber belajar, padahal siswa memiliki fasilitas buku paket. Hal ini berbeda dengan teori yang disampaikan Allen \& Lynn (2010) bahwa anak pada usia 11-12 tahun menyukai tantangan dan senang mencari informasi dari sumber lain.

Permasalahan lain yang ditemukan peneliti berdasarkan hasil observasi pada Oktober 2019 di sekolah dasar Kecamatan Purworejo menunjukkan bahwa selain kemandirian belajar, siswa juga mengalami permasalahan pada regulasi diri. Regulasi diri siswa yang masih rendah dibuktikan dengan ditemukan bahwa siswa enggan mengoreksi ulang pekerjaannya ketika sudah selesai mengerjakan soal dan teman yang lain belum selesai, siswa tetap melanjutkan bermain ketika diingatkan untuk segera menyelesaikan tugas saat jam pelajaran berlangsung. Hal lain adalah ketika mengerjakan soal, beberapa siswa memilih untuk mengarang jawaban padahal diperbolehkan mencari di buku dan materinya sudah disampaikan. Selain itu, siswa juga tidak tepat waktu masuk kelas ketika waktu istirahat sudah berakhir.

Permasalahan terakhir yang ditemukan adalah mengenai kedisiplinan siswa yang masih rendah. Rendahnya kedisiplinan siswa dibuktikan dengan masih adanya siswa yang terlambat datang ke sekolah, siswa tidak lengkap dalam mengenakan atribut sekolah ketika upacara, siswa terlambat mengumpulkan bahkan ada yang tidak mengerjakan tugas yang diberikan oleh guru, dan masih ditemukannya siswa yang tidak masuk ketika hari Jumat-Sabtu.

Ormrod (2008) menyampaikan bahwa kemandirian belajar memungkinkan siswa menjadi individu yang mampu menyelesaikan masalah dalam belajar. Pendapat lain disampaikan Shohoudi, Khalil \& Mohammad (2015) bahwa kemandirian belajar akan meningkatkan kemauan untuk belajar pada siswa. Oleh karena itu, kemandirian belajar pada siswa penting untuk diteliti agar hasil dari belajar dapat optimal. Kemandirian belajar yang muncul dalam diri siswa dapat disebabkan oleh berbagai macam faktor. Salah satu faktor yang memberi pengaruh pada kemandirian belajar adalah regulasi diri dan kedisiplinan siswa.

Berdasarkan uraian tersebut dapat dijelaskan bahwa regulasi diri dan kedisiplinan dapat mempengaruhi kemandirian belajar siswa. Namun, belum diketahui besarnya pengaruh regulasi diri dan kedisiplinan terhadap kemandirian belajar siswa. Hal ini yang mendasari perlunya kajian lebih lanjut terkait pengaruh regulasi diri dan kedisiplinan siswa terhadap kemandirian siswa sekolah dasar. Berdasarkan permasalahan yang telah dikemukakan, maka pelaksanaan penelitian ini bertujuan untuk membuktikan regulasi diri secara parsial berpengaruh terhadap kemandirian belajar siswa, kedisiplinan secara parsial berpengaruh terhadap kemandirian belajar siswa, regulasi diri dan kedisiplinan secara bersama-sama berpengaruh terhadap kemandirian belajar siswa.

\section{METODE}

Penelitian ini menggunakan pendekatan penelitian kuantitatif. Jenis penelitian yang digunakan adalah ex-post facto yang bertujuan untuk mengetahui ada tidaknya pengaruh regulasi diri dan kedisiplinan terhadap kemandirian belajar siswa sekolah dasar. Penelitian ini dilaksanakan di SD Negeri Kepatihan Purworejo, SD Negeri Sebomenggalan, SD Negeri 2 Baledono, Kecamatan Purworejo, Kabupaten Purworejo. Sampel penelitian sebanyak 56 orang siswa yang dipilih secara random. Pengumpulan data dilakukan dengan menggunakan instrumen kuesioner sakala psikologi serta dianalisis dengan menggunakan statistik deskriptif dan statistik inferensial melalui analisis regresi. 
Setelah diperoleh data mengenai regulasi diri, kedisiplinan, dan kemandirian belajar, dilakukan penggolongan subjek menjadi tiga kategori yaitu rendah, sedang, tinggi. Pengkategorian ini dilakukan dengan kriteria yang disampaikan oleh Azwar (2011:101) sebagai berikut.

Tabel 1. Pengkategorian Data Penelitian

\begin{tabular}{cc}
\hline Nilai & Kategori \\
\hline $\mathrm{X}<\mathrm{M}-1 \mathrm{SD}$ & Rendah \\
$\mathrm{M}-1 \mathrm{SD} \leq \mathrm{X}<\mathrm{M}+1 \mathrm{SD}$ & Sedang \\
$\mathrm{M}+1 \mathrm{SD} \leq \mathrm{X}$ & Tinggi \\
\hline
\end{tabular}

\section{HASIL DAN PEMBAHASAN}

\section{Hasil}

Penelitian ini menggunakan beberapa tahap analisis. Pertama yaitu tahap analisis deskriptif. Tahap yang kedua yaitu uji prasyarat analisis yang meliputi uji normalitas, uji linearitas, dan uji multikolinearitas. Tahap yang ketiga yaitu menguji hipotesis. Setelah dilakukan beberapa tahap tersebut kemudian dilakukan pembahasan hasil penelitian. Masing-masing tahap tersebut diuraikan sebagai berikut.

1. Hasil Analisis Deskriptif Variabel Regulasi Diri

Data variabel regulasi diri $\left(\mathrm{X}_{1}\right)$ diperoleh dari 56 siswa menggunakan skala penilaian regulasi diri siswa. Setelah dilakukan pengambilan data, maka dapat disajikan deskripsi data ukuran kecenderungan memusat yaitu mean, median, dan mode, serta ukuran keragaman yaitu variance, standar deviation, skor minimal, dan skor maksimal dalam tabel berikut.

Tabel 2. Statistik Deskriptif Variabel Regulasi Diri

\begin{tabular}{lc}
\hline Statistik & Koefisien \\
\hline Mean & 54,53 \\
Median & 54 \\
Mode & 54 \\
Std. Deviation & 7,1 \\
Variance & 50,54 \\
Maximum & 66 \\
Minimum & 35 \\
\hline
\end{tabular}

Berdasarkan Tabel 2 tersebut, diketahui bahwa sebaran skor regulasi diri siswa bergerak antara 35 sebagai skor terendah hingga 66 sebagai skor tertinggi. Adapun varians data sebesar 50,54 dengan simpangan baku sebesar 7,10. Selain itu, rata-rata skor diperoleh sebesar 54,5 dengan modus 54 dan median 54. Sesuai data tersebut, kemudian disajikan pengkategorian regulasi diri siswa untuk mengetahui kecenderungan regulasi diri siswa bedasarkan data yang ada sebagai berikut.

Tabel 3. Sebaran Data Regulasi Diri Siswa Berdasarkan Pengkategorian Skor

\begin{tabular}{cccc}
\hline Interval & Kategori & Frek & $(\%)$ \\
\hline $\mathrm{X} \leq 44$ & Rendah & 4 & 7,1 \\
$45 \leq \mathrm{X}<55$ & Sedang & 29 & 51,8 \\
$55 \leq \mathrm{X}$ & Tinggi & 23 & 41,1 \\
\hline
\end{tabular}

Berdasarkan Tabel 3 tersebut, diketahui bahwa sebanyak 7,1\% atau 4 siswa menilai regulasi diri dengan kategori rendah, 51,8\% atau 29 siswa menilai regulasi diri dengan kategori sedang, $41,1 \%$ atau 23 siswa menilai regulasi diri dengan kategori tinggi. Jika ditinjau berdasarkan skor rata-rata yang telah diperoleh sebelumnya yaitu 54,5, maka dapat dikemukakan bahwa skor regulasi diri siswa berada pada kategori sedang. 
Jurnal Penelitian Ilmu Pendidikan,13 (1), 2020 - 25

Arifah Yuli Purwaningsih \& Herwin

2. Hasil Analisis Deskriptif Variabel Kedisiplinan

Data variabel Kedisiplinan $\left(\mathrm{X}_{2}\right)$ diperoleh dari 56 siswa menggunakan skala penilaian kedisiplinan siswa. Setelah dilakukan pengambilan data, maka dapat disajikan deskripsi data ukuran kecenderungan memusat yaitu mean, median, dan mode, serta ukuran keragaman yaitu variance, standar deviation, skor minimal, dan skor maksimal dalam tabel berikut.

Tabel 4. Statistik Deskriptif Variabel Kedisiplinan

\begin{tabular}{lc}
\hline Statistik & Koefisien \\
\hline Mean & 37,44 \\
Median & 38 \\
Mode & 36 \\
Std. Deviation & 6,9 \\
Variance & 47,63 \\
Maximum & 50 \\
Minimum & 23 \\
\hline
\end{tabular}

Berdasarkan Tabel 4 tersebut, diketahui bahwa sebaran skor kedisiplinan siswa bergerak antara 23 sebagai skor terendah hingga 50 sebagai skor tertinggi. Adapun varians data sebesar 47,63 dengan simpangan baku sebesar 6,9. Selain itu, rata-rata skor diperoleh sebesar 37,44 dengan modus 36 dan median 38. Sesuai data tersebut, kemudian disajikan pengkategorian regulasi diri siswa untuk mengetahui kecenderungan kedisiplinan siswa bedasarkan data yang ada sebagai berikut.

Tabel 5. Sebaran Data Kedisiplinan Siswa Berdasarkan Pengkategorian Skor

\begin{tabular}{cccc}
\hline Interval & Kategori & Frek & $(\%)$ \\
\hline $\mathrm{X} \leq 31$ & Rendah & 12 & 21,43 \\
$32 \leq \mathrm{X}<40$ & Sedang & 23 & 41,07 \\
$40 \leq \mathrm{X}$ & Tinggi & 21 & 37,50
\end{tabular}

Berdasarkan Tabel 5 tersebut, diketahui bahwa sebanyak $21,43 \%$ atau 12 siswa menilai kedisiplinan dengan kategori rendah, 41,07\% atau 23 siswa menilai kedisiplinan dengan kategori sedang, 37,5\% atau 21 siswa menilai kedisiplinan dengan kategori tinggi. Jika ditinjau berdasarkan skor rata-rata yang telah diperoleh sebelumnya yaitu 37,44, maka dapat dikemukakan bahwa skor kedisiplinan siswa berada pada kategori sedang.

3. Hasil Analisis Deskriptif Variabel Kemandirian

Data variabel Kemandirian (Y) diperoleh dari 56 siswa menggunakan skala penilaian kemandirian siswa. Setelah dilakukan pengambilan data, maka dapat disajikan deskripsi data ukuran kecenderungan memusat yaitu mean, median, dan mode, serta ukuran keragaman yaitu variance, standar deviation, skor minimal, dan skor maksimal dalam tabel berikut.

Tabel 6. Statistik Deskriptif Variabel Kemandirian

\begin{tabular}{lc}
\hline Statistik & Koefisien \\
\hline Mean & 58,64 \\
Median & 58,5 \\
Mode & 54 \\
Std. Deviation & 5,9 \\
Variance & 35,9 \\
Maximum & 47 \\
Minimum & 74 \\
\hline
\end{tabular}

Berdasarkan Tabel 6 tersebut, diketahui bahwa sebaran skor kemandirian siswa bergerak antara 47 sebagai skor terendah hingga 74 sebagai skor tertinggi. Adapun varians data sebesar 35,9 dengan simpangan baku sebesar 5,9. Selain itu, rata-rata skor diperoleh sebesar 58,64 dengan modus 54 dan 
median 58,5. Sesuai data tersebut, kemudian disajikan pengkategorian kemandirian siswa untuk mengetahui kecenderungan kedisiplinan siswa bedasarkan data yang ada sebagai berikut.

Tabel 7. Sebaran Data Kemandirian Siswa Berdasarkan Pengkategorian Skor

\begin{tabular}{cccc}
\hline Interval & Kategori & Frek & $(\%)$ \\
\hline $\mathrm{X} \leq 55$ & Rendah & 21 & 37,5 \\
$56 \leq \mathrm{X}<64$ & Sedang & 26 & 46,4 \\
$65 \leq \mathrm{X}$ & Tinggi & 9 & 16,07 \\
\hline
\end{tabular}

Berdasarkan Tabel 7 tersebut, diketahui bahwa sebanyak 37,5\% atau 21 siswa menilai kemandirian dengan kategori rendah, 46,4\% atau 26 siswa menilai kemandirian dengan kategori sedang, 16,07\% atau 9 siswa menilai kemandirian dengan kategori tinggi. Jika ditinjau berdasarkan skor rata-rata yang telah diperoleh sebelumnya yaitu 58,64, maka dapat dikemukakan bahwa skor kemandirian siswa berada pada kategori sedang.

\section{Hasil Pengujian Persyaratan Analisis}

Pengujian persyaratan analisis dilakukan untuk menentukan statistik yang digunakan. Uji persyaratan yang dilakukan ialah pengujian normalitas data, pengujian linieritas dan pengujian mulikolinieritas.

Uji normalitas dilakukan untuk mengetahui apakah data yang diperoleh berdistribusi normal atau tidak. Pengujian normalitas dilakukan dengan menggunakan Kolmogorov Smirnov yang dihitung menggunakan SPSS versi 22 for windows. Hasil penelitian dikatakan normal apabila nilai Asymp. Sig yang diperoleh $>0,05$, sedangkan apabila hasil yang diperoleh $\leq 0,05$ maka tidak berdistribusi normal. Berikut ini disajikan ringkasan hasil pengujian normalitas data.

Tabel 8. Hasil Pengujian Normalitas

\begin{tabular}{lcc}
\hline \multicolumn{1}{c}{ Variabel } & Asymp. Sig & Keterangan \\
\hline Kemandirian Belajar & 0,058 & Normal \\
Regulasi Diri & 0,200 & Normal \\
Kedisiplinan & 0,200 & Normal \\
\hline
\end{tabular}

Berdasarkan Tabel 8 tersebut, menggunakan perhitungan melalui SPSS versi 22 for windows diperoleh nilai Asymp. Sig untuk variabel kemandirian belajar 0,058, Regulasi diri 0,200 dan kedisiplinan 0,200 Nilai Asymp. Sig dari regulasi diri, kedisiplinan, kemandirian belajar memiliki nilai di atas 0,05 maka distribusi data dari setiap variabel telah berdistribusi normal.

Pengujian selanjutnya ialah uji linieritas. Uji linieritas dilakukan untuk mengetahui apakah pengaruh masing-masing variabel bebas yang dijadikan prediktor mempunyai hubungan linear atau tidak terhadap variabel terikat. Pengujian linearitas dilakukan dengan menggunakan test of linearity dengan bantuan SPSS versi 22 for windows. Kriterianya, jika nilai sig. Linierity di bawah 0,05 dan nilai sig. deviation from linearity di atas 0.05 maka variabel dikatakan mempunyai hubungan linear. Sebaliknya, jika nilai sig. Linierity di atas 0,05 dan nilai sig. deviation from linearity di bawah 0.05 maka variabel dikatakan mempunyai hubungan tidak linear. Berdasarkan hasil pengujian semua hubungan antar variabel memiliki nilai sig $<0,05$. Hal tersebut bermakna bahwa hubungan antar variabel adalah linier.

Uji multikolinearitas yaitu uji asumsi untuk regresi linear ganda. Asumsi dari multikolinearitas adalah bahwa variabel bebas harus terbebas dari multikolinearitas. Uji multikolinearitas dilakukan dengan melihat nilai tolerance dan Variance Inflation Factor (VIF). Jika menggunakan alpha/tolerance $=10 \%$ atau 0,10 maka VIF $=10$. Apabila hasil yang diperoleh VIFhitung $<\mathrm{VIF}=10$ dan semua tolerance variabel bebas di atas $10 \%$, maka dapat disimpulkan tidak terjadi multikolinearitas. Hasli pengujian tersebut disajikan pada Tabel 9 sebagai berikut.

Tabel 9. Pengujian Mulikolinieritas

\begin{tabular}{lcc}
\hline Variabel & Tollerance & VIF \\
\hline Regulasi Diri & 0,909 & 1,101 \\
Kedisiplinan & 0,909 & 1,101 \\
\hline
\end{tabular}


Berdasarkan Tabel 9 tersebut, maka dapat disimpulkan bahwa tidak terjadi multikoliniertas. Untuk itu, statistik parametrik dapat digunakan pada pengujian hipotesis selanjutnya.

\section{Hasil Pengujian Hipotesis}

Pengujian hipotesis dilakukan untuk mengetahui pengaruh variabel regulasi diri dan kedisiplinan secara parsial dan simultan terhadap kemandirian belajar. Pengujian hipotesis dilakukan dengan mencari koefisien determinan yang digunakan untuk mengetahui tingkat ketepatan paling baik dalam analisis regresi, ini ditunjukkan oleh besarnya koefisien determinasi antara 0 (nol) dan 1 (satu). Selain itu, koefisien determinasi digunakan untuk mengetahui persentase perubahan variabel terikat ( $\mathrm{Y}$ ) yang disebabkan oleh variabel bebas (X). Uji koefisien determinasi dilakukan secara parsial dan simultan.

Tabel 10. Hasil Pengujian Parsial

\begin{tabular}{lcc}
\hline \multicolumn{1}{c}{ Koefisien } & \multicolumn{2}{c}{ Variabel } \\
& Bila $\mathrm{X}_{1}$ tetap & Bila $\mathrm{X}_{2}$ tetap \\
\hline Korelasi Parsial & 0,585 & 0,302 \\
Determinasi Parsial & 0,342 & 0,009 \\
$\mathrm{~T}_{\text {hitung }}$ & 4,910 & 0,315 \\
Singnifikansi & 0,000 & 0,024 \\
\hline
\end{tabular}

Berdasarkan Tabel 10 tersebut, hasil perhitungan diperoleh nilai $r^{2}$ yaitu 0,342 (jika $X_{1}$ tetap) dengan thitung 4,910 dan nilai signifikansi 0,000 . Nilai signifikansi $0,000<0,05$ maka dapat dikatakan signifikan. Oleh karena itu, dapat disimpulkan bahwa Ho ditolak dan Ha diterima. Hal ini berarti terdapat pengaruh signifikan kedisiplinan terhadap terhadap kemandirian belajar apabila regulasi diri tetap.

Lebih lanjut dari perhitungan diperoleh nilai $\mathrm{r}^{2}$ yaitu 0,009 (jika $\mathrm{X}_{2}$ tetap) dengan $\mathrm{t}_{\text {hitung }} 0,315$ dan nilai signifikansi 0,024. Nilai signifikansi $0,000<0,05$ maka dapat dikatakan signifikan. Oleh karena itu, dapat disimpulkan bahwa Ho ditolak dan Ha diterima. Hal ini berarti terdapat pengaruh yang signifikan regulasi diri terhadap kemandirian belajar apabila kedisiplinan siswa tetap.

Pengujian determinasi secara simultan $\left(\mathrm{r}^{2}\right)$ dilakukan dengan bantuan SPSS versi 22 for windows. Hasil $\left(r^{2}\right)$ yang diperoleh sebesar 0,343 , artinya persentase sumbangan pengaruh variabel regulasi diri $\left(\mathrm{X}_{1}\right)$ dan kedisiplinan $\left(\mathrm{X}_{2}\right)$ terhadap kemandirian belajar $(\mathrm{Y})$ sebesar $34,3 \%$, sedangkan $65,7 \%$ dipengaruhi oleh variabel lain yang tidak diteliti dalam penelitian ini. Kemudian, untuk mengetahui apakah secara bersama-sama variabel bebas berpengaruh signifikan terhadap variabel terikat maka

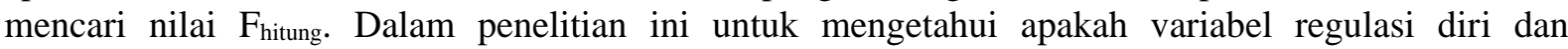
kedisiplinan berpengaruh secara signifikan atau tidak terhadap variabel kemandirian belajar. Kriteria pengambilan keputusan hipotesis dalam penelitian ini nilai signifikansi $<0,05$. Berdasarkan hasil perhitungan regresi ganda dengan menggunakan bantuan SPSS versi 22 for windows diperoleh hasil $F_{\text {hitung }} 13.833$ dengan signifikansi $0,000<0,05$. Dengan demikian, dapat disimpulkan bahwa regulasi diri dan kedisiplinan secara bersama-sama berpengaruh signifikan terhadap kemandirian belajar siswa.

\section{Pembahasan}

Hasil temuan pertama membuktikan bahwa regulasi diri secara parsial berpengaruh signifikan terhadap kemandirian belajar siswa. Hal ini menunjukkan bahwa peningkatan dan penurunan kedisiplinan siswa dipengaruhi oleh regulasi diri siswa. Adanya pengaruh ini ditunjukkan dengan hasil koefisien determinasi parsial variabel regulasi diri sebesar 34,2\% dengan nilai signifikansi 0,000 yang berarti bahwa regulasi diri secara parsial berpengaruh signifikan terhadap kemandirian belajar.

Regulasi diri merupakan proses mengendalikan diri dalam belajar. Dimulai dengan menyusun serangkaian aktivitas belajar sesuai dengan tujuan yang sudah ditetapkan sebelumnya. Setelah tujuan tercapai, kemudian dilanjutkan dengan mengevaluasi hasil untuk dapat diperbaiki dan ditingkatkan agar mencapai hasil yang optimal dikemudian hari. Regulasi diri belajar ini harus ditanamkan sejak dini untuk melatih siswa dalam disiplin juga kemandirian dalam belajar (Ruminta, 2018: 34). Hong \& Yoon (2012) mengatakan ada tiga faktor yang berpengaruh terhadap kemandirian belajar, yaitu efikasi diri, regulasi diri dan juga dukungan yang diberikan oleh orang tua. Sedangkan menurut Huynh \& Cecilia 
(2009:4) kemandirian belajar dipengaruhi oleh adanya manajemen diri, kontrol diri dan keinginan untuk belajar.

Siswa yang memiliki kemandirian mampu menyusun dan menetapkan tujuan belajarnya sendiri karena siswa mampu menjadi pengendali diri sendiri dalam kegiatan belajarnya (Mudjiman, 2007: 7-8). Cervon \& Pervin (2012) juga mengemukakan pendapat bahwa regulasi diri merupakan suatu proses kepribadian yang melibatkan perilaku motivasi diri secara langsung. Siswa yang memiliki regulasi diri mampu memotivasi diri mereka sendiri untuk menyusun tujuan-tujuan pribadi, merencanakan strategi yang akan dilakukan agar dapat mencapai tujuan tersebut, hingga mengevaluasi perilaku yang telah dilakukan. Ketika siswa mampu mengevaluasi perilakunya, siswa dapat lebih bertanggung jawab untuk belajar sehingga tercipta kemandirian untuk belajar pada dirinya sendiri dengan adanya regulasi diri.

Regulasi diri secara substansial dibentuk pada periode awal melalui efek lingkungan dan biologis (Torres, 2011; Liman \& Tapeli, 2019). Lebih lanjut Mudjiman (2007) menjelaskan mengenai seseorang yang sedang menjalankan kegiatan belajar mandiri lebih ditandai dan ditentukan oleh motif yang mendorongnya belajar bukan kenampakan fisik kegiatan belajarnya. Adanya motif dalam diri siswa menandakan bahwa siswa melakukan kegiatan belajar atas kemauan dan regulasi diri tanpa ada paksaan dari pihak lain. Jika siswa sudah melakukan belajar dengan mandiri dapat dikatakan bahwa siswa memiliki regulasi diri pada dirinya.

Berdasarkan hasil penelitian dan pendapat di atas, secara teoritik regulasi diri secara parsial memberikan pengaruh pada kemandirian belajar siswa, sehingga hasil penelitian ini menunjukkan kebenaran teori-teori yang sudah ada.

Hasil temuan kedua membuktikan bahwa kedisiplinan secara parsial berpengaruh signifikan terhadap kemandirian belajar siswa. Hal ini menunjukkan bahwa peningkatan dan penurunan kemandirian belajar siswa dipengaruhi oleh kedisiplinan siswa. Adanya pengaruh ini ditunjukkan dengan hasil koefisien determinasi parsial variabel kedisiplinan sebesar $0,9 \%$ dengan nilai signifikansi 0,024 yang berarti bahwa kedisiplinan secara parsial berpengaruh signifikan terhadap kemandirian belajar.

Sebagian besar aspek kehidupan kita sehari-hari cenderung mengalami perubahan besar, untuk itu kemandirian akan memungkinkan individu untuk merespons tuntutan pekerjaan, keluarga, dan masyarakat yang terus berubah (Kopzhassarovaa, Akbayevaa, Eskazinovaa, Belgibayevaa \& Tazhikeyeva, 2016). Sikap kemandirian sangatlah penting dimiliki oleh siswa. Jika dilihat dari situasi kehidupan saat ini fenomena yang terjadi secara langsung maupun tidak langsung mempengaruhi kehidupan siswa. Terdapat 4 (empat) faktor penyebab kemandirian antara lain: (1) gen atau keturunan, orang tua yang memiliki sifat kemandirian tinggi seringkali menurunkan anak yang memiliki sifat mandiri juga; (2) pola asuh orang tua, cara orang tua mengasuh atau mendidik anak akan mempengaruhi perkembangan kemandirian anak; (3) kedisiplinan, proses pendidikan di sekolah yang kurang mengembangkan sikap disiplin dalam pendidikan dan cenderung menekankan indoktrinasi tanpa argumentasi akan menghambat kemandirian anak; dan (4) masyarakat, sistem kehidupan masyarakat yang terlalu menekankan pentingnya hirarki struktur social kurang menghargai menifestasi potensi anak dalam kegiatan produktif dapat menghambat perkembangan kemandirian anak (Ali \& Asrori, 2006:118119).

Pendapat diperkuat lagi oleh Aqib (2014) bahwa faktor penyebab kemandirian di atas dapat dilihat bahwa kedisiplinan menjadi faktor yang turut menentukan kemandirian belajar siswa. Salah satu strategi yang dapat membuat siswa menjadi mandiri yaitu dengan kedisiplinan, karena sikap disiplin bertujuan agar dapat menjaga anak dari perilaku yang menyimpang dan hal-hal yang dapat menganggu dalam proses pembelajaran.

Berdasarkan hasil penelitian dan pendapat di atas, secara teoritik regulasi diri secara parsial memberikan pengaruh pada kemandirian belajar siswa, sehingga hasil penelitian ini menunjukkan kebenaran teori-teori yang sudah ada.

Hasil temuan ketiga membuktikan bahwa regulasi diri dan kedisiplinan secara bersama-sama berpengaruh signifikan terhadap kemandirian belajar siswa. Hal ini menunjukkan bahwa peningkatan dan penurunan kedisiplinan siswa dipengaruhi oleh regulasi diri dan kedisiplinan siswa. Adanya pengaruh ini ditunjukkan dari variabel regulasi diri dan variabel kedisiplinan secara bersama-sama menghasilkan nilai koefisien determinasi simultan sebesar 34,3\% terhadap kemandirian belajar siswa. Nilai signifikansi yang diperoleh sebesar 0,000 sehingga dapat diartikan bahwa regulasi diri dan kedisiplinan secara bersama-sama berpengaruh signifikan terhadap kemandirian belajar siswa. Ketika 
siswa mampu menguasai regulasi diri dengan baik dan memeiliki kedisiplinan tinggi maka akan semakin baik pula tingkat kemandirian belajar siswa. Begitu pula sebaliknya, apabila siswa kurang dalam regulasi diri dan kedisiplinannya rendah, maka tingkat kemandirian belajar rendah bahkan tidak muncul.

Pada konteks sistem sekolah, siswa yang disiplin adalah siswa yang perilaku dan tindakan sesuai dengan aturan dan peraturan sekolah yang telah ditentukan (Ali, Dada, Isiaka, \& Salmon, 2014). Disiplin idealnya lebih dari sekadar mematuhi aturan dan peraturan dan mensyaratkan kemampuan pelajar untuk membedakan apa yang benar atau salah (Gitome, Katola, \& Nyabwari, 2013). Kedisiplinan siswa di sekolah berpengaruh positif terhadap pencapaian akademik siswa (Simba, Agak \& Kabuka, 2016).

Menurut Blanford (Aqib, 2014:116), disiplin adalah pengembangan mekanisme internal diri siswa sehingga siswa dapat mengendalikan dirinya (regulasi diri) sendiri. Siswa yang terbiasa dalam disiplin akan mempergunakan waktu sebaik-baiknya di rumah maupun di sekolah sehingga akan menunjukkan kesiapannya dalam proses pembelajaran di sekolah, sedangkan siswa yang tidak disiplin mereka kurang menunjukkan kesiapannya dalam belajar. Mereka akan menunjukkan perilaku yang tidak mandiri dalam hal belajar. Siswa yang sudah terbiasa disiplin berarti ia juga memiliki regulasi diri yang baik dalam dirinya, sikap dan perbuatan disiplin yang dilakukan bukan lagi dirasakan sebagai suatu beban, melainkan suatu tindakan yang sudah biasa dilakukan setiap hari. Sehingga penyebab rendahnya kemandirian siswa adalah karena faktor kedisiplinan, juga faktor regulasi diri dimana jika siswa sudah menunjukkan sikap yang disiplin dan regulasi diri yang baik maka permasalahan kemandirian belajar tersebut akan berkurang. Begitupun sebaliknya jika kedisiplinan dan regulasi diri masih menjadi masalah utama bagi siswa maka kemandirian yang diinginkan sulit tercapai.

\section{PENUTUP}

Berdasarkan hasil penelitian dan pembahasan maka diperoleh tiga kesimpulan yaitu: (1) regulasi diri secara parsial berpengaruh terhadap kemandirian belajar siswa; (2) kedisiplinan secara parsial berpengaruh terhadap kemandirian belajar siswa; serta (3) regulasi diri dan kedisiplinan secara bersamasama berpengaruh terhadap kemandirian belajar siswa.

Berdasarkan kesimpulan penelitian ini, maka disarankan hal-hal sebagai berikut. (1) Siswa dapat memotivasi diri untuk meningkatkan regulasi diri dan memiliki kedisiplinan sehingga kemandirian belajar dapat meningkat lebih optimal. (2) Kepala sekolah diharapkan dapat meningkatkan pengawasan dan melakukan pemantauan atau juga dapat mengadakan kegiatan yang menumbuhkan regulasi diri dan kedisiplinan siswa sehingga kemandirian belajar meningkat. (3) Guru diharapkan dapat membantu siswa menguasai regulasi diri dengan memberikan motivasi melalui cerita dan sebagainya ketika sedang mengajar. Selain itu guru dapat melakukan pembelajaran menjadi lebih kreatif dan bersifat student centered. Guru dapat mengoptimalkan kedisiplinan dengan berbagai cara seperti memberikan sanksi dan reward yang positif secara adil dan korektif, serta memberikan contoh yang baik ketika di kelas maupun di luar kelas sehingga siswa dapat meningkatkan kemandirian belajar siswa.

\section{UCAPAN TERIMA KASIH}

Rasa terimakasih kami sampaikan kepada Kepala Sekolah dan Guru SD Negeri Kepatihan Purworejo, SD Negeri Sebomenggalan, SD Negeri 2 Baledono, Kecamatan Purworejo, Kabupaten Purworejo dan peserta didik kelas IV, kelas V dan kelas VI.

\section{DAFTAR PUSTAKA}

Ali, A. A., Dada, I. T., Isiaka, G. A., \& Salmon, S. A. (2014). Types, causes and management of indiscipline acts among secondary school students in Shomolu Local Government Area of Lagos State. Journal of Studies in Social Sciences, 8(2), 254-287.

Ali, M. \& Asrori, M. (2006). Psikologi remaja perkembangan peserta didik. Jakarta: PT. Bumi Aksara. Allen, K.E., \& Lynnn, R.M. (2010). Profil perkembangan anak, pra kelahiran hingga usia 12 tahun edisi 5. (Terjemahan Valentino). Jakarta: PT Indeks.

Aqib, Z. (2014). Pendidikan karakter membangun perilaku positif anak bangsa. Bandung: CV. Yrama Widya.

Azwar, S. (2011). Metode penelitian. Yogyakarta: Pustaka Pelajar. 
Cervone, D. \& Pervin, L. A. (2012). Kepribadian: Teori dan penelitian. (Alih bahasa: Aliya Tusyani, dkk). Jakarta: Salemba Humanika.

Gitome, J. W, Katola, M. T., \& Nyabwari, B. G. (2013). Correlation between students' discipline and performance in the Kenya Certificate of Secondary Education. International Journal of Education and Research, 1(8), 1-10.

Hong, S. C. \& Yoon, P. Y. (2012). An analysis of the relationship between self-study, private tutoring, and self-efficacy on self-regulated learning. Journal of Educational Policy, (October 2011), 113 144.

Huynh, D., Stuart, T.H., \& Cecilia, M.P. (2009). The impact of advanced pharmacy practice experiences on students "readiness for self-directed learning. American Journal of Pharmaceutical Education, 73(4), 1-8.

Kopzhassarovaa, U., Akbayevaa, G., Eskazinovaa, Z., Belgibayevaa, G., \& Tazhikeyeva, A. (2016). Enhancement of students' independent learning through their critical thinking skills development. International Journal of Environmental \& Science Education, 11(18), 11585-11585.

Liman, B., \& Tapeli, K. (2019). A study on the effects of self-regulation skills education program on self-regulation skills of six-year-old children. Educational Research and Reviews, 14(18), 647654.

Mudjiman, H. (2007). Belajar mandiri (self-motivated learning). Surakarta: UNS Press.

Ormrod, J. E. (2008). Educational psychology developing learners sixth edition (psikologi pendidikan membantu siswa tumbuh dan berkembang edisi keenam jilid 2). (Alih bahasa: Prof. Dr. Amitya Kumara). Jakarta: Erlangga.

Ruminta. (2018). Perbedaan regulasi diri belajar pada siswa sekolah dasar kelas vi ditinjau dari jenis kelamin. Jurnal Muara Ilmu Sosial, Humaniora, dan Seni, 2(1), 34.

Shohoudi, M., Khalil, Z., \& Mohammad, R. F., Fathi, G., \& Safari, Z. (2015). Relationship of teaching efficiency with academic self-efficacy and self-directed learning among english language students: University students' perspectives. Educational Research in Medical Sciences, 4(2), 23-32.

Simba, N. O., Agak, J. O., \& Kabuka, E. K. (2016). Impact of discipline on academic performance of pupils in public primary schools in Muhoroni Sub-County, Kenya. Journal of Education and Practice, 7(6), 164-173.

Torres M. (2011). Understanding self-regulation, links to school readiness, and implications for intervening with high-risk children. Unpublished Doctorate Thesis, Pennsylvania State University, USA. 